\title{
O passado no banco dos réus: uma análise das decisões das Cortes Supremas argentina e brasileira sobre a validade das "leis de impunidade",
}

Carlos Artur Gallo

\section{Resumo}

Este trabalho faz uma análise comparada de demandas que questionavam a validade de leis que garantem e/ou garantiram a impunidade dos setores envolvidos com a repressão política praticada durante as ditaduras de Segurança Nacional. Foram selecionados dois casos para comparação: o "Caso Simón”, julgado em junho de 2005 pela Corte Suprema de Justicia de la Nación (CSJN) argentina, e a Arguição por Descumprimento de Preceito Fundamental (ADPF) n 153, julgada em abril de 2010 pelo Supremo Tribunal Federal brasileiro. São comparadas as decisões e busca-se identificar o que as explica, verificando sua conexão com as políticas de memória implementadas em cada contexto.

Palavras-chave: Ditaduras de Segurança Nacional. Poder Judiciário. Políticas de memória.

I Uma versão preliminar deste artigo foi apresentada na ATI4 - Poder Judicial, derechos humanos, política y justicia, durante o "9o Congresso da Associação Latino-Americana de Ciência Política (ALACIP)", realizado em julho de 2017, em Montevidéu - Uruguai.

2 Doutor em Ciência Política pela Universidade Federal do Rio Grande do Sul (UFRGS), com estágio doutoral realizado na Universidade Complutense de Madri. Professor do Departamento de Sociologia e Política e do Programa de Pós-Graduação em Ciência Política da Universidade Federal de Pelotas (UFPel). Contato: galloadv@gmail.com atribua a autoria da obra, forneça um link para a licença, e indicar se foram feitas alterações. 


\section{Introdução}

Entre as décadas de 1960 e 1970, auge da Guerra Fria, países do Cone Sul (entre os quais o Brasil e a Argentina) passaram por golpes civis-militares que deram início a uma série de ditaduras de Segurança Nacional. Ideologicamente alinhadas à Doutrina de Segurança Nacional (DSN), estas ditaduras foram responsáveis por um conjunto significativo de violaçôes aos direitos humanos, tendo sido perseguidas, presas, torturadas, exiladas, mortas e desaparecidas milhares de pessoas que foram consideradas inimigas internas pelas Forças de Segurança (PADRÓS, 2008).

Semelhanças, no que tange ao tipo de regime autoritário, à parte, o modo como as ditaduras de Segurança Nacional chegaram ao fim nos países mencionados foi marcado por diferenças importantes, fazendo com que os processos de transiçáo à democracia argentino e brasileiro fossem classificados, por estudiosos do período, como sendo representantes de dois modelos distintos ${ }^{3}$. $\mathrm{Na}$ Argentina, analistas classificaram o processo transicional, ocorrido aproximadamente entre junho de 1982 e dezembro de 1983, como sendo uma "transição por ruptura", tendo em vista que a saída das Forças Armadas das estruturas de poder ocorre de forma acelerada e sem que estas tivessem capacidade de estipular os termos de sua saída do controle do Poder Executivo, após uma grande crise gerada, entre outros fatores, pelo fracasso econômico, pelo alcance e profundidade da violência política e pelo fracasso na Guerra das Malvinas, conforme análises de: Munck e Leff (1997); Novaro e Palermo (2003). No Brasil, ocorreu uma "transição negociada" ou "pactada", visto que é a própria coalizão civil-militar no poder quem inicia e controla o processo transicional, que se estenderia por quase 11 anos, entre 1974 e 1985, garantindo aos setores que saíam de cena um conjunto de prerrogativas bastante significativo, conforme, entre outros, o estudo de Arturi (2001).

3 Os processos de transição à democracia que se seguiram ao iniciado em 1974, em Portugal, quando a Revolução dos Cravos deu fim à ditadura do Estado Novo português, serviram de base para o estabelecimento de uma agenda de pesquisas que, conhecida como "transitologia", mobilizou acadêmicos e acadêmicas de diversos países entre as décadas de 1970 e 1990. Os estudos mais importantes sobre os diferentes processos de mudança de regime que ocorreram inicialmente no Sul da Europa e na América Latina e, depois, na África e no Leste Europeu, foram organizados pelo cientista político argentino Guillermo O'Donnell em parceria com Philippe Schmitter e Laurence Whitehead (O'DONNELL; SCHMITTER, 1988a; O'DONNELL; SCHMITTER, WHITEHEAD, 1988b; O'DONNELL; SCHMITTER, WHITEHEAD, 1988c). 
Com o início dos processos de transição à democracia e o fim das ditaduras na região, uma série de demandas relacionadas aos crimes cometidos pelo aparato repressivo no período autoritário começaram a ganhar fôlego nesses países, resultando nas mais diversas formas de enfrentamento do tema por parte do estado e suas instituiçóes, tais como: a criação de organismos como uma Comissão da Verdade (algo que, no caso argentino, ocorreu ainda em 1983, quando terminou a ditadura e Raúl Alfonsín tomou posse como presidente e criou a Comissão Nacional sobre a Desaparição de Pessoas (CONADEP), a implementação de políticas públicas prevendo a concessão de indenizaçóes às vítimas da repressão e/ou a seus familiares (algo que, no caso brasileiro, começou a avançar a partir de 1995, com a ediçáo da Lei no 9.140), a construçáo de memoriais e espaços de memória sobre o período, assim como a realização de julgamentos dos responsáveis pelos crimes cometidos durante a vigência dos regimes de exceção, entre outras medidas.

Autores alinhados à agenda de estudos transitológicos chegaram a debater, em alguma medida, como os países que estavam saindo de um regime autoritário e construindo as bases de um novo regime democrático poderiam lidar com o saldo da repressão. O’Donnell e Schmitter (1988a, por exemplo, nas primeiras conclusóes do projeto "Transiçóes do regime autoritário", mencionavam que o não enfrentamento do tema poderia gerar problemas em curto, médio e longo prazo, sendo necessário estabelecer as garantias da não repetição e punir os responsáveis pela repressão para fortalecer o novo regime. Huntington (1994), por sua vez, reconheceu que era preciso não se esquecer dos crimes que foram cometidos por agentes do Estado, embora não defendesse a sua punição como sendo a melhor estratégia com vistas à consolidação das novas democracias.

Apesar das diferenças de perspectiva sobre a necessidade (e conveniência) de punição dos envolvidos com as violaçóes aos direitos humanos praticadas pelas ditaduras, análises elaboradas a partir dos estudos transitológicos convergiram para o estabelecimento de algumas hipóteses preliminares. Uma delas que, acredita-se, pode servir como um ponto de partida para este estudo sugeria que o modo como ocorreu a transição à democracia em cada contexto poderia repercutir na manutenção de resquícios, legados do autoritarismo junto à cultura e às instituiçôes, repercutindo na 
forma como seriam processadas as demandas por memória, verdade e justiça; nesse sentido, os estudos de: Brito, Aguilar e González (2002); Morlino (2013); Pereira (2010) e Pinto (2013).

Considerando o exposto, a partir das decisóes produzidas na Argentina e no Brasil nos julgamentos de causas que tratam da validade das "leis de impunidade"4, neste artigo são analisadas as formas como a mais alta instância do Poder Judiciário destes países tratou, no cenário político iniciado após a transição à democracia, as questóes relacionadas: a) às violaçóes aos direitos humanos cometidas pelo aparato repressivo instalado em nome da Segurança Nacional; b) à identificação e responsabilização dos agentes envolvidos nestes crimes; c) às possibilidades de recomposição da história do período, obtida com a elucidação das circunstâncias em que se deram as violaçóes aos direitos humanos dos opositores das ditaduras.

Os casos selecionados para a análise são a Arguição por Descumprimento de Preceito Fundamental no 153 (ADPF no 153), julgada no Supremo Tribunal Federal (STF) brasileiro em 2010, e o "Caso Simón”, recurso julgado pela Corte Suprema de Justicia de la Nación (CSJN, 2005) argentina em 2005. Em linhas gerais, a despeito das diferenças técnicas de ambos, que serão sintetizadas em outra seção deste estudo, os dois julgamentos trataram questóes em comum, uma vez que foi preciso que os e as integrantes das Cortes Supremas brasileira e argentina se pronunciassem sobre o alcance e a validade de leis que tornam e tornaram possível o náo julgamento dos responsáveis pelas violaçóes aos direitos humanos cometidas durante as ditaduras. No caso julgado pelo STF, isso se deu com a apreciação de um pedido de esclarecimento da interpretação da Lei da Anistia. No caso julgado pela CSJN, com a análise de um recurso interposto por um antigo repressor, reivindicando para si a aplicação de leis que, revogadas pelo Congresso Nacional argentino em 2003, haviam garantido até então a impunidade de centenas de repressores ${ }^{5}$.

4 Tendo em vista que na Argentina não há uma Lei de Anistia como a que foi editada no Brasil, mas sim um conjunto de normas que limitou elou impossibilitou o processamento e a punição daqueles que cometeram violações aos direitos humanos, para esta pesquisa adota-se a nomenclatura "leis de impunidade" - expressão utilizada, por exemplo, em Norris (1992) - para fazer referência a esse conjunto de regras editadas nos dois paises analisados.

5 Embora tenham sido organizadas medidas com este objetivo (ver, por exemplo, o Projeto de Lei $n^{\circ}$ 7.430, de 20 10, proposto pela Deputada Federal Luciana Genro, do PSOL), no Congresso Nacional brasileiro nunca pros- 
No que se relaciona ao problema que guia a pesquisa, pretende-se responder ao seguinte questionamento: Que elementos ajudam a entender como, enquanto o STF estabeleceu que a interpretação da anistia recíproca, embora contrária à legislação internacional de proteçáo aos direitos humanos, devia ser mantida, a CSJN adotou a posição de que leis que garantem a impunidade são inconstitucionais e que os crimes cometidos pelo aparato repressivo náo prescrevem?

O objetivo geral é compreender a diferença no tratamento do tema das violaçóes por parte da Suprema Corte do Judiciário argentino e brasileiro. Para atingir esse objetivo, são identificados e analisados os argumentos utilizados no julgamento das açôes sobre a validade das leis de impunidade que tramitaram na Corte Suprema, na Argentina, e no Supremo Tribunal, no Brasil.

O método de pesquisa empregado é a análise comparada. Intimamente relacionado ao próprio desenvolvimento da Ciência Política, o uso de uma perspectiva comparada mostra-se bastante útil às Ciências Sociais na medida em que comparar é a "ferramenta" que se apresenta como uma substituta adequada ao método experimental, que é facilmente utilizado por pesquisadores de outras áreas (BADIE; HERMET, 1993, p. 15).

Se o número reduzido de casos a ser comparado pode ser entendido como limitado por parte dos pesquisadores que utilizam essa metodologia, visto que o poder explicativo das inferências extraídas da comparação de poucos casos tenderia a ser menor, conforme mencionado por Landman (2011), a opção pelo uso de uma análise comparada para poucos casos; contudo, é viável, desde que sejam observados alguns critérios por parte do pesquisador (NOHLEN, 2013).

Uma vez que o objeto selecionado para essa pesquisa permite a identificação de categorias de análise aplicáveis aos dois contextos, ambas as decisóes a serem analisadas foram emitidas em instituiçóes semelhantes, e ambas tratam de um tema em comum, a escolha de uma perspectiva comparada parece justificada. Afinal, além de uma comparação favorecer 
a identificação e a análise das semelhanças e diferenças contidas nos casos escolhidos, realizá-la auxilia, de igual modo, no estabelecimento de conexóes entre o conteúdo dos processos transicionais argentino e brasileiro, seus reflexos no julgamento dos processos envolvendo as leis de impunidade e, finalmente, na forma como a memória da repressão seria tratada nesses países.

Para sintetizar o conteúdo dos julgamentos ${ }^{6}$ e realizar a comparação pretendida, foram elaborados quadros síntese dos votos de todas as Ministras e Ministros que participaram das votaçóes realizadas pelo STF e pela CSJN. Nos quadros elaborados, o conteúdo dos votos foi categorizado a partir de quatro eixos: $1^{\circ}$ ) a posiçáo do ministro-votante sobre a possibilidade de revisão da interpretaçáo da lei de anistia (no caso brasileiro) ou a validade das "leis de impunidade" (para o caso argentino); 2o) a visão que cada votante possui a respeito da aplicação do direito internacional dos direitos humanos em âmbito interno; $3^{\circ}$ ) o entendimento dos Ministros sobre a prescrição das violaçôes praticadas pelo aparato repressivo; $4^{\circ}$ ) o posicionamento dos integrantes da Corte a respeito da satisfação do direito à memória e à verdade.

Ao comparar o discurso enunciado pelos Ministros ao darem solução jurídica para cada uma das categorias de análise selecionadas, busca-se, ao entender o argumento elaborado para fundamentar cada voto, identificar a leitura que cada membro do STF e da CSJN possuía a respeito do processo de transição à democracia ocorrido nos países e das normas que impossibilitam ou relativizam a punição de agentes da repressão.

No que se relaciona à exposição, a mesma se encontra organizada em três seçóes. Na primeira delas, apresenta-se uma síntese da ADPF no 153 e do "Caso Simón", na qual são contextualizadas e identificadas as principais questóes abordadas no julgamento destas demandas. Na sequência, na segunda parte do estudo, é realizada uma primeira comparação do conteúdo dos julgamentos a partir das categorias referidas. $\mathrm{Na}$ terceira seção do artigo, são identificados elementos que ajudam a entender as diferenças entre

6 Os votos dos integrantes das Supremas Cortes são documentação pública, disponivel para consulta em sites oficiais do Poder Judiciário dos dois países e somam, juntos, mais de 500 páginas. 
os votos emitidos no STF (2010) e na CSJN (2005), realizando-se uma análise comparada das decisóes e seus efeitos.

\section{As leis de impunidade em xeque: uma aproximação}

Embora açôes judiciais visando à responsabilização dos envolvidos na tortura ou morte de indivíduos que foram considerados "inimigos internos" da ditadura brasileira já tenham sido ajuizadas desde a década de $1970^{7}$, uma ação como a que chegou à Suprema Corte em outubro de 2008 trazia consigo algo diferente para o debate, gerando novas expectativas. A partir a proposição da $\mathrm{ADPF} \mathrm{n}^{\circ} 153$ pelo Conselho Federal da OAB no STF, neste sentido, a força da Lei da Anistia seria colocada à prova.

Proposta em um contexto no qual a opiniáo pública brasileira vinha sendo gradativamente ocupada com notícias sobre a violência praticada no passado recente do país (dentre outros fatos, a intensificação de atividades da Comissão da Anistia e a publicação do $\mathrm{PNDH}-3$, que previa a criação de uma Comissão da Verdade, contribuíram neste sentido), a ADPF $\mathrm{n}^{\mathrm{o}} 153$ foi julgada pelos Ministros do Supremo em duas sessóes respectivamente realizadas nos dias 28 e 29 de abril de 2010 .

Em síntese, a Arguição propunha: 1) que a Lei de Anistia brasileira, quando redigida, fora elaborada com redação obscura, de modo que, valendo-se de uma interpretação abrangente a respeito do disposto no $\$ 1^{\circ}$ do art. $1^{\circ}$ da Lei, teriam sido abrangidos pela regra tanto aqueles que eram considerados opositores do regime civil-militar como aqueles que haviam cometido crimes em nome do Estado autoritário; 2) que, diante da controvérsia a respeito da abrangência da Lei, o STF devia avaliar o caso esclarecendo o alcance da regra, interpretando-a de acordo com preceitos e princípios fundamentais previstos na Constituição Federal ${ }^{8}$.

7 A viúva de Vladimir Herzog, por exemplo, ingressou com ação declaratória, ganhando na Justiça, em outubro de 1978, sentença que reconhecia a responsabilidade do Estado brasileiro pela tortura e morte do jornalista morto no DOI-CODI paulista.

8 No Relatório apresentado pelo Ministro Eros Grau para o julgamento da Arguição (Acórdão da ADPF $n 1^{\circ}$ 153, p. 6), consta que: "A eventual declaração, por esta Corte, do recebimento do $\S 1^{\circ}$ do art. $1^{\circ}$ da Lei 6.683 implicaria, segundo o arguente, desrespeito [i] ao dever, do Poder Público, de não ocultar a verdade; [ii] aos principios democrático e republicano; [iii] ao princípio da dignidade da pessoa humana". 
O Ministro Eros Grau, designado Relator do processo, e, portanto, o primeiro a publicizar seu entendimento a respeito da questáo, votou utilizando um método de análise que observava o contexto histórico da edição da Lei da Anistia, com vistas à compreensão do significado e dos objetivos da norma no momento da transição política. Assim, ao analisar os fatos daquele momento da história do país, o Ministro concluiu, como fica evidente no trecho do voto reproduzido a seguir, que o objetivo da Lei foi conceder uma anistia bilateral (recíproca), pois, segundo o Acórdáo da ADPF no 153:

Há quem se oponha ao fato de a migração da ditadura para a democracia política ter sido uma transição conciliada, suave em razão de certos compromissos. Isso porque foram todos absolvidos, uns absolvendo-se a si mesmos. Ocorre que os subversivos a obtiveram, a anistia, à custa dessa amplitude. Era ceder e sobreviver ou não ceder e continuar a viver em angústia (em alguns casos, nem mesmo viver). Quando se deseja negar o acordo político que efetivamente existiu resultam fustigados os que se manifestaram politicamente em nome dos subversivos. (STF, 2010, p. 37).

O voto da Ministra Cármen Lúcia acompanhando o Relator exemplifica a linha de pensamento que seria adotada pela maioria da Corte:

Como em outras oportunidades históricas, o Brasil de 1979 construiu o que se conheceu como processo de transição política, pelo qual a sociedade civil, representada pelas entidades de importância e legitimidade reconhecidas, como o Conselho Federal da Ordem dos Advogados do Brasil, fez concessões de monta e com conseqüências [sic] gravíssimas, como a que se contém no $\S 1^{\circ}$ do art. $1^{\circ}$ da Lei n. 6683/79, para chegar a uma outra fase política. (STF, 2010, p. 96).

O voto do Ministro Eros Grau considerando a Arguição improcedente foi acompanhado pela maioria dos integrantes da Corte (Ministros Cármen Lúcia, Ellen Gracie, Marco Aurélio, Celso de Mello, Cezar Peluso e Gilmar Mendes), sendo o voto vencedor do processo. Divergindo, o Ministro Ricardo Lewandowski se manifestou pela parcial procedência da ADPF no 153 e considerou que:

[...] a atecnia, proposital ou involuntária - não importa agora - da redação do $\S 1^{\circ}$ do art. $1^{\circ}$ da Lei 6.683/1979, no ponto em que alude à conexão entre crimes comuns e políticos, para o efeito de estender a anistia aos agentes estatais, vem causando, por sua inegável equivocidade, desde quando veio a lume, considerável perplexidade dentre aqueles que buscaram interpretá-lo. (STF, 2010, p. 110). 
A simples menção à conexão no texto legal contestado, a toda evidência, não tem o condão de estabelecer um vínculo de caráter material entre os crimes políticos cometidos pelos opositores do regime e os delitos comuns atribuídos aos agentes do Estado, para o fim de conferir-lhes o mesmo tratamento jurídico. (STF, 2010, p. 112).

O voto da divergência de Lewandowski foi acompanhado pelo Ministro Carlos Ayres Britto. Juntos, ambos reconheceram que era necessário esclarecer a interpretação corrente dada à Lei da Anistia brasileira, relativizando a leitura segundo a qual a norma teria anistiado tanto as vítimas da repressão como os envolvidos com as violaçóes aos direitos humanos. Como resultado da votação, realizada no STF, em 2010, a ADPF no 153 foi julgada improcedente pela maioria dos votantes: sete Ministros votaram contra o pedido de esclarecimento, dois Ministros votaram pela parcial procedência da causa.

No tocante à Argentina, o uso do Judiciário para a realização de demandas de familiares de vítimas da repressão foi constante, gerando resultados que, mesmo limitados com a concessão de indultos e as leis de "Punto Final" e "Obediencia Debida" editadas na década de 1980 para barrar os julgamentos iniciados logo após o retorno à democracia (além de outros membros das Forças Armadas, em 1985 os antigos integrantes das Juntas Militares que comandaram a Argentina durante a ditadura foram condenados à prisão pelas violaçóes praticadas), foram bastante significativos no contexto que ficou marcado pela obtenção da verdade por meios alternativos.

Se na década de 1990, durante os mandatos do presidente Carlos Saúl Menem (1989-1999), predominou a impossibilidade de processar e punir os responsáveis pelas violaçóes aos direitos humanos ocorridas entre 1976 e 1983, a partir de março de 2001, com a sentença proferida pelo Juiz Gabriel Cavallo no julgamento de uma causa sobre a apropriação de Claudia Victoria Poblete ${ }^{9}$ iniciada no ano 2000 pelo Centro de Estudios Legales y Sociales (CELS), passa a ganhar fôlego uma nova fase

9 Claudia Victoria Poblete é filha dos militantes politicos José Poblete (chileno) e Gertrudis Marta Hlaczik (argentina). Sequestrados em 1978, o casal e a filha foram levados para o centro clandestino de detenção "El Olimpo", em Buenos Aires. Lá, o casal foi torturado e desaparecido, e a criança, com apenas 8 meses de idade, teve sua identidade subtraída, indo para adoção. 
na luta por justiça no país. Isso porque, a partir da decisão de Cavallo, na qual as "leis de impunidade" foram consideradas inconstitucionais, uma nova série de açóes relacionadas aos crimes da ditadura foi iniciada (CELS, 2010, p. 63-64; RAUSCHENBERG, 2014, p. 582).

$\mathrm{O}$ incremento das possibilidades de uso do Judiciário para além dos processos sobre as crianças subtraídas por agentes da repressão, convém mencionar, não surge isoladamente, podendo ser apontado como um fator que contribui para tanto, conforme o estudo de Rui Calado (2014), a chegada de Néstor Kirchner à Presidência da Nação, em maio de 2003.

Voltando à sentença do Juiz Cavallo, após a mesma ser confirmada em segunda instância em novembro de 2001, novo recurso é interposto pela defesa de Julio Simón (cujo codinome era “Turco Julián”), um dos agentes da repressão condenados por sua participação na apropriação de Claudia Victoria Poblete e na desaparição dos seus pais. Assim, em 2002, aquele que ficaria conhecido como o "Caso Simón" ("Fallo Simón”) chega à Corte Suprema de Justicia la Nación argentina, vindo a ser julgado em 14 de junho de 2005.

Em linhas gerais, a alegação da defesa do réu consistia na tese de que as leis de "Punto Final" e de "Obediencia Debida" eram válidas, devendo prevalecer em detrimento do que decidiram as instâncias judiciais inferiores. Afinal, e para os defensores de Simón, aceitar o argumento de que a normativa internacional poderia ser aplicada ao caso, reconhecendo a validade da Lei no 25.779 (que havia declarado a nulidade das "leis de impunidade" via Poder Legislativo), seria o mesmo que admitir que leis posteriores aos fatos gerassem efeitos retroativos prejudiciais aos envolvidos nos crimes da ditadura.

O Ministro Enrique S. Petracchi, Presidente da CSJN na época do julgamento, utiliza parte de seu voto com a análise do objetivo das leis editadas em 1986 e 1987, que acabaram limitando o uso do Judiciário argentino para a punição dos agentes da repressão. Ao fazê-lo, o Acórdão do "Caso Simón", menciona que, naquele contexto,

[...] a pesar de las deficiencias de la técnica legislativa utilizada, la ratio legis era evidente: amnistiar los graves hechos delictivos cometidos durante el anterior régimen militar, en el entendimiento de que, frente al grave conflicto de intereses que la sociedad argentina enfrentaba 
en ese momento, la amnistía aparecía como la única vía posible para preservar la paz social. La conservación de la armonía sociopolítica era valorada por el legislador como un bien jurídico sustancialmente más valioso que la continuación de la persecución penal de los beneficiarios de la ley. (CSJN, 2005, p. 107).

[...] en la medida en que dichas normas obstaculizan el esclarecimiento y la efectiva sanción de actos contrários a los derechos reconocidos en los tratados mencionados, impiden el cumplimiento del deber de garantía a que se ha comprometido el Estado argentino, y resultan inadmisibles. [...] Sin embargo "esas disposiciones de olvido y perdón no pueden poner a cubierto las más severas violaciones a los derechos humanos, que significan un grave menosprecio de la dignidad del ser humano y repugnan a la conciencia de la humanidad". (CSJN, 2005, p. I16-117).

Isso significa, conforme Petracchi (p. 107-108), que alteraçóes na conjuntura política pós-anos 1980 poderiam justificar uma reconsideração sobre a vigência dessas normas. Não reconhecer a inconstitucionalidade de leis que impedem a elucidação e o julgamento dos crimes que foram cometidos pela repressão seria, nesse sentido, equivocado, uma vez que a Argentina assumiu deveres e compromissos no âmbito internacional com vistas à proteçáo dos direitos humanos. Por essa razão, consequentemente, o Ministro adota posição contra a prescrição da punição das violaçóes ocorridas, e, ao se posicionar sobre a validade da Lei no 25.779 , referindo ainda que a esta deve ser reconhecida, visto que o Poder Legislativo havia se manifestado sobre algo que o Judiciário faria da mesma maneira.

Na mesma linha de Petracchi, outros colegas da Corte Suprema argentina reforçaram a ideia de que a manutenção da vigência das "leis de impunidade”, além de inconstitucional, poderia levar o Estado argentino a ser sancionado por organismos internacionais pelo descumprimento da normativa existente. Neste sentido, encontra-se, entre outras, a manifestação do Ministro Eugenio Raúl Zaffaroni, quando afirma:

Que se aproxima mucho más al núcleo del problema la posición que funda la legitimidad de la nulidad de las leyes de marras en el derecho internacional vigente como derecho interno. Tal como se ha señalado, es claro que las leyes que se pretenden anular chocan frontalmente con la ley internacional. Pueden citarse varios textos incorporados a nuestra Constitución en función del inc. 22 del art. 75, pero basta recordar la mencionada jurisprudencia de la Corte Interamericana de Derechos Humanos en su sentencia del 14 
de marzo de 200I, en el caso "Barrios Altos (Chumbipuma Aguirre y otros vs. Perú)" serie C No 75: "Esta Corte considera que son inadmisibles las disposiciones de amnistía, las disposiciones de prescripción y el establecimiento de excluyentes de responsabilidad que pretendan impedir la investigación y sanción de los responsables de las violaciones graves de los derechos humanos tales como la tortura, las ejecuciones sumarias, extralegales o arbitrarias y las desapariciones forzadas, todas ellas prohibidas por contravenir derechos inderogables reconocidos por el Derecho Internacional de los Derechos Humanos". La Corte Interamericana considera que "las mencionadas leyes carecen de efectos jurídicos y no pueden seguir representando um obstáculo para la investigación de los hechos que constituyen este caso ni para la identificación y el castigo de los responsables, ni pueden tener igual o similar impacto respecto de otros casos de violación de los derechos consagrados en la Convención Americana acontecidos en el Perú”. (CSJN, 2005, p. 23I).

A única dissidência no julgamento foi apresentada pelo Ministro Carlos S. Fayt, sendo a maioria da CSJN, como fica evidente no "Quadro 1", favorável à declaração de inconstitucionalidade das "leis de impunidade". Divergindo do voto do Ministro Petracchi, Fayt se posicionou no julgamento defendendo o princípio da "irretroatividade penal". Disse, ainda, que as leis questionadas não impediram a persecução penal de agentes da repressáo, apenas fixaram limites para a realização dos processos, algo que, segundo Fayt, não constitui um problema, visto que a demanda por punição não pode ser considerada sinônimo de punição ilimitada. No sentido mencionado, os seguintes trechos do voto sintetizam o pensamento do Ministro:

En efecto, debe existir una ley que prohíba o mande una conducta, para que una persona pueda incurrir en falta por haber obrado u omitido obrar en determinado sentido y que además se determinen las penas a aplicar (Fallos: 304:892). Consecuentemente, de dicha norma constitucional, que consagra el principio nullum crimen, nulla poena sino lege praevia se deriva que la ley penal no puede ser retroactiva en cuanto a la descripción del tipo legal ni en cuanto a la adjudicación de la sanción. (CSJN, 2005, p. 306-307).

Que la imposibilidad de condenar en la presente causa al entonces suboficial de la Policia Federal Julio Héctor Simón no puede equipararse a la "indefensión de las víctimas y a la perpetuación de la impunidad" de la que se da cuenta en "Barrios Altos". Cabe reiterar que las leyes de "punto final" y "obediencia debida" no sustrajeron a las víctimas de protección judicial, simplemente establecieron un plazo para denunciar y, posteriormente, la exoneración de quienes eran subordinados. El derecho de la víctima a obtener la condena de una persona en concreto, de ninguna manera se compadece con la visión del castigo en un Estado de Derecho. El deber de investigar en modo alguno implica condenar a todos los 
sujetos involucrados, sin distinción de responsabilidad y sin límite temporal. En efecto, la no impunidad no significa necesariamente que todos los involucrados deban ser castigados. (CSJN, 2005, p. 340).

Quadro I - Síntese do posicionamento dos Ministros sobre a demanda principal da ADPF n 153 e do "Caso Simón”

\begin{tabular}{|c|c|c|c|}
\hline \multicolumn{2}{|c|}{$\begin{array}{l}\text { Favorável à revisão da interpretação da lei } \\
\qquad \text { de anistia? }\end{array}$} & \multicolumn{2}{|c|}{$\begin{array}{c}\text { Favorável à manutenção da validade das } \\
\text { "leis de impunidade"? }\end{array}$} \\
\hline \multicolumn{2}{|c|}{ Brasil } & \multicolumn{2}{|c|}{ Argentina } \\
\hline Ministros do STF & Posicionamento & Ministros da CSJN & Posicionamento \\
\hline $\begin{array}{l}\text { CEZAR } \\
\text { PELUSO }\end{array}$ & NÃO & $\begin{array}{l}\text { ENRIQUE S. } \\
\text { PETRACCHI }\end{array}$ & NÃO \\
\hline $\begin{array}{l}\text { EROS } \\
\text { GRAU }\end{array}$ & NÃO & $\begin{array}{l}\text { CARLOS S. } \\
\text { FAYT }\end{array}$ & SIM \\
\hline $\begin{array}{l}\text { CELSO DE } \\
\text { MELLO }\end{array}$ & NÃO & $\begin{array}{l}\text { ANTONIO } \\
\text { BOGGIANO }\end{array}$ & NÃO \\
\hline $\begin{array}{l}\text { MARCO } \\
\text { AURÉLIO }\end{array}$ & NÃO & $\begin{array}{l}\text { JUAN CARLOS } \\
\text { MAQUEDA }\end{array}$ & NÃO \\
\hline $\begin{array}{l}\text { ELLEN } \\
\text { GRACIE }\end{array}$ & NÃO & $\begin{array}{l}\text { EUGENIO RAÚL } \\
\text { ZAFFARONI }\end{array}$ & NÃO \\
\hline $\begin{array}{l}\text { GILMAR } \\
\text { MENDES }\end{array}$ & NÃO & $\begin{array}{l}\text { ELENA I. HIGHTON } \\
\text { DE NOLASCO }\end{array}$ & NÃO \\
\hline $\begin{array}{l}\text { AYRES } \\
\text { BRITTO }\end{array}$ & EM PARTE & $\begin{array}{l}\text { RICARDO LUIS } \\
\text { LORENZETTI }\end{array}$ & NÃO \\
\hline $\begin{array}{c}\text { RICARDO } \\
\text { LEWANDOWSKI }\end{array}$ & EM PARTE & $\begin{array}{l}\text { CARMEN } \\
\text { ARGIBAY }\end{array}$ & NÃO \\
\hline $\begin{array}{l}\text { CÁRMEN } \\
\text { LÚCIA }\end{array}$ & NÃO & & \\
\hline
\end{tabular}

Fonte: Elaborado pelo autor da pesquisa com base nos Acórdãos da ADPF n० 153 (STF, 2010) e do "Caso Simón" (CSJN, 2005). 


\section{As leis de impunidade em xeque: comparando as decisões da Suprema Corte na Argentina e no Brasil}

Avançando com a exposição, procede-se a seguir com uma primeira comparaçáo dos resultados das sessóes de julgamento realizadas nas Cortes Supremas brasileira e argentina. Para organizar a análise, os dados foram sistematizados segundo as categorias mencionadas anteriormente: o posicionamento dos votantes sobre a aplicação do direito internacional dos direitos humanos (ver Quadro 2), a interpretação de cada um sobre a prescrição dos crimes cometidos por agentes da repressão (ver Quadro 3) e a posição dos Ministros sobre o direito à memória e à verdade (ver Quadro 4).

Dos nove Ministros que votaram no julgamento da ADPF, quatro deles (Eros Grau, Cezar Peluso, Celso de Mello e Gilmar Mendes) se posicionaram contrários à aplicaçáo de legislação elaborada no plano internacional para o caso, enquanto outros quatro (Cármen Lúcia, Ellen Gracie, Marco Aurélio e Ayres Britto) não mencionaram seu entendimento sobre a questão. Os que votam contra o uso do direito internacional para o caso alegam que algumas dessas previsóes foram internalizadas pelo Estado brasileiro após os fatos terem ocorrido e/ou que o ordenamento jurídico brasileiro não admite, por razóes atinentes à técnica jurídica, que o direito internacional seja utilizado como fonte de Direito em casos específicos.

$\mathrm{O}$ único Ministro que utiliza normativa internacional para formular seu voto, reconhecendo-a como fonte de direito interno, é o Ministro Ricardo Lewandowski, que vota pela parcial procedência da Arguição. Ainda assim, ele o faz de modo seletivo, sem adentrar, por exemplo, na discussão sobre crimes de lesa-humanidade, temática que repercutiria de modo direto no entendimento e no debate da Corte sobre a imprescritibilidade de alguns dos crimes cometidos pelo aparato repressivo. 
Quadro 2 - Síntese do posicionamento dos Ministros sobre direito internacional dos direitos humanos

\begin{tabular}{|c|c|c|c|}
\hline \multicolumn{4}{|c|}{ Favorável à aplicação do direito internacional dos direitos humanos para decidir o caso? } \\
\hline \multicolumn{2}{|c|}{ Brasil } & \multicolumn{2}{|c|}{ Argentina } \\
\hline Ministros do STF & Posicionamento & Ministros da CSJN & Posicionamento \\
\hline $\begin{array}{l}\text { CEZAR } \\
\text { PELUSO }\end{array}$ & NÃO & $\begin{array}{l}\text { ENRIQUE S. } \\
\text { PETRACCHI }\end{array}$ & SIM \\
\hline $\begin{array}{l}\text { EROS } \\
\text { GRAU }\end{array}$ & NÃO & $\begin{array}{c}\text { CARLOS S. } \\
\text { FAYT }\end{array}$ & $\mathrm{NÃO}$ \\
\hline $\begin{array}{l}\text { CELSO DE } \\
\text { MELLO }\end{array}$ & NÃO & $\begin{array}{l}\text { ANTONIO } \\
\text { BOGGIANO }\end{array}$ & SIM \\
\hline $\begin{array}{l}\text { MARCO } \\
\text { AURÉLIO }\end{array}$ & NÃO MENCIONA & $\begin{array}{l}\text { JUAN CARLOS } \\
\text { MAQUEDA }\end{array}$ & SIM \\
\hline $\begin{array}{l}\text { ELLEN } \\
\text { GRACIE }\end{array}$ & NÃO MENCIONA & $\begin{array}{l}\text { EUGENIO RAÚL } \\
\text { ZAFFARONI }\end{array}$ & SIM \\
\hline $\begin{array}{l}\text { GILMAR } \\
\text { MENDES }\end{array}$ & NÃO & $\begin{array}{c}\text { ELENA I. HIGHTON } \\
\text { DE NOLASCO }\end{array}$ & SIM \\
\hline $\begin{array}{l}\text { AYRES } \\
\text { BRITTO }\end{array}$ & NÃO MENCIONA & $\begin{array}{l}\text { RICARDO LUIS } \\
\text { LORENZETTI }\end{array}$ & SIM \\
\hline $\begin{array}{c}\text { RICARDO } \\
\text { LEWANDOWSKI }\end{array}$ & SIM & $\begin{array}{l}\text { CARMEN } \\
\text { ARGIBAY }\end{array}$ & SIM \\
\hline $\begin{array}{l}\text { CÁRMEN } \\
\text { LÚCIA }\end{array}$ & NÃO MENCIONA & & \\
\hline
\end{tabular}

Fonte: Elaborado pelo autor da pesquisa com base nos Acórdãos da ADPF no 153 (STF, 2010) e do "Caso Simón" (CSIN, 2005).

$\mathrm{Na}$ CSJN, dos oito Ministros que participaram do julgamento do "Caso Simón", sete deles se posicionaram favoráveis à aplicação de normativa internacional sobre direitos humanos para o caso. $\mathrm{O}$ único voto contrário foi o do Ministro Carlos S. Fayt, que defendeu uma interpretação pautada no princípio da irretroatividade penal, segundo a qual normas posteriores aos fatos não podem ser aplicadas se não acarretam benefício ao réu, adotando um posicionamento marcado pela defesa da primazia do direito interno frente ao direito internacional. 
Os Ministros favoráveis ao uso da normativa internacional para julgar o caso se manifestaram, ainda que com pequenas diferenças interpretativas e argumentativas, no sentido de que a inegável evoluçáo dos direitos humanos ocorrida durante o século XX, assim como a internalização de diversas regras elaboradas no plano internacional ao ordenamento argentino, justificava o uso destas previsóes, independentemente de estas terem sido elaboradas e/ou internalizadas antes das violaçóes aos direitos humanos terem sido praticadas. Assim, fazendo uso do conceito de crimes de lesa-humanidade, esses Ministros apresentaram um posicionamento jurídico embasado na crença de que fazer parte da comunidade internacional requer a proteção dos direitos humanos desde sempre, sendo desnecessário, diante da evidente atrocidade de alguns crimes, que eles tenham sido tipificados pela lei.

Quadro 3 - Síntese do posicionamento dos Ministros sobre prescrição

\begin{tabular}{|c|c|c|c|}
\hline \multicolumn{4}{|c|}{ Favorável à prescrição da punição das violações? } \\
\hline \multicolumn{2}{|c|}{ Brasil } & \multicolumn{2}{|c|}{ Argentina } \\
\hline Ministros do STF & Posicionamento & Ministros da CSJN & Posicionamento \\
\hline $\begin{array}{l}\text { CEZAR } \\
\text { PELUSO }\end{array}$ & SIM & $\begin{array}{l}\text { ENRIQUE S. } \\
\text { PETRACCHI }\end{array}$ & NÃO \\
\hline $\begin{array}{l}\text { EROS } \\
\text { GRAU }\end{array}$ & NÃO MENCIONA & $\begin{array}{l}\text { CARLOS S. } \\
\text { FAYT }\end{array}$ & SIM \\
\hline $\begin{array}{l}\text { CELSO DE } \\
\text { MELLO }\end{array}$ & SIM & $\begin{array}{l}\text { ANTONIO } \\
\text { BOGGIANO }\end{array}$ & NÃO \\
\hline $\begin{array}{l}\text { MARCO } \\
\text { AURÉLIO }\end{array}$ & SIM & $\begin{array}{l}\text { JUAN CARLOS } \\
\text { MAQUEDA }\end{array}$ & NÃO \\
\hline $\begin{array}{l}\text { ELLEN } \\
\text { GRACIE }\end{array}$ & NÃO MENCIONA & $\begin{array}{l}\text { EUGENIO RAÚL } \\
\text { ZAFFARONI }\end{array}$ & NÃO \\
\hline $\begin{array}{l}\text { GILMAR } \\
\text { MENDES }\end{array}$ & SIM & $\begin{array}{c}\text { ELENA I. HIGHTON } \\
\text { DE NOLASCO }\end{array}$ & NÃO \\
\hline $\begin{array}{l}\text { AYRES } \\
\text { BRITTO }\end{array}$ & NÃO MENCIONA & $\begin{array}{l}\text { RICARDO LUIS } \\
\text { LORENZETTI }\end{array}$ & NÃO \\
\hline $\begin{array}{c}\text { RICARDO } \\
\text { LEWANDOWSKI }\end{array}$ & $\begin{array}{l}\text { DEPENDE DO } \\
\text { CRIME }\end{array}$ & $\begin{array}{l}\text { CARMEN } \\
\text { ARGIBAY }\end{array}$ & NÃO \\
\hline $\begin{array}{l}\text { CÁRMEN } \\
\text { LÚCIA }\end{array}$ & NÃO MENCIONA & & \\
\hline
\end{tabular}

Fonte: Elaborado pelo autor da pesquisa com base nos Acórdãos da ADPF n 153 (STF, 20I0) e do

"Caso Simón” (CSIN, 2005). 
No que se refere ao debate em torno da prescrição (ver "Quadro 3") dos crimes cometidos pelo aparato repressivo, quatro Ministros do STF (Eros Grau, Cármen Lúcia, Ellen Gracie e Ayres Britto) consideraram que ela somente deveria ser analisada de acordo com o resultado do julgamento da Arguição ${ }^{10}$. Outros quatro membros da Corte (Marco Aurélio, Celso de Mello, Cezar Peluso e Gilmar Mendes), por sua vez, optaram por se posicionar, já no julgamento da $\mathrm{ADPF}$, em favor da prescrição da pretensão punitiva dos crimes ocorridos durante a ditadura. Ao fazê-lo, esses Ministros consideraram que se aplicava aos atos praticados por agentes da repressão os prazos prescricionais previstos pela legislação brasileira, tendo sido já atingido o limite temporal máximo fixado pela lei (30 anos para o Direito Penal).

Apresentando um entendimento diferente, o Ministro Lewandowski defendeu posição em parte contrária à aplicação automática da prescrição dos crimes cometidos pelo aparato repressivo existente entre 1964 e 1985. Votando nesse sentido, o Ministro referiu que a prescrição deveria ser apurada caso a caso. Além disso, fez referência à normativa internacional que prevê a imprescritibilidade de violaçóes aos direitos humanos (embora não tenha aprofundado o debate sobre a sua aplicação ao caso), evocando, ainda, precedente do STF sobre a suspensão do prazo prescricional para crimes considerados de "caráter permanente" (caso do desaparecimento forçado).

De modo semelhante à apresentação de uma posição sobre o uso do direito internacional dos direitos humanos em âmbito interno, parte dos Ministros do STF parece ter optado por náo se comprometer com essa questão naquele momento, dizendo que considerava a análise do tema dependente do resultado geral do julgamento. Com quase metade dos votos da Corte favoráveis à prescrição da punição dos crimes cometidos em nome da Segurança Nacional no país, coube ao Ministro Lewandowski, solitariamente, dar algum tratamento mais progressista à temática.

Ainda assim, é possível observar, na análise do seu voto, que há uma falta de clareza no que diz respeito à aplicação geral das normas de prescrição às violaçôes ocorridas durante a ditadura. Produzindo um voto segundo

10 Do ponto de vista técnico-jurídico, cumpre referir, os Ministros do STF não precisavam posicionar-se, quando do julgamento da ADPF no 153, a respeito do tema da prescrição. 
o qual o prazo prescricional deveria ser analisado caso a caso, dependendo do crime cometido, o Ministro formulou um posicionamento que, comparado ao caso argentino, como será analisado na sequência, parece juridicamente pouco ousado.

Dentre os Ministros da CSJN, como é possível verificar no Quadro 3, sete deles consideraram que os crimes de lesa-humanidade cometidos por agentes da repressão não estariam prescritos, tendo em vista a normativa internacional existente. O Ministro Fayt, divergindo dos demais integrantes da Corte, sustentou que os crimes estariam prescritos de acordo com as normas de direito interno argentino, afirmando, ainda, que não podia admitir que uma lei criada ou internalizada após os fatos pudesse ser aplicada retroativamente prejudicando o réu.

De um modo geral, ao se posicionarem a respeito da ocorrência (ou não) da prescriçáo da punição dos envolvidos em violaçóes aos direitos humanos durante a ditadura, os Ministros da Corte argentina deram uma demonstração de coerência em seus votos. Nada mais coerente, nesse sentido, que aqueles que embasaram seu julgamento em doutrina e legislação elaboradas no plano internacional tenham, ao se posicionar sobre o tema, sido contrários a uma interpretaçáo pró-prescrição, visto que a normativa internacional prevê a imprescritibilidade dos crimes de lesa-humanidade.

Quadro 4 - Síntese do posicionamento dos Ministros sobre direito à memória e à verdade

\begin{tabular}{|c|c|c|c|}
\hline \multicolumn{3}{|c|}{ Favorável à satisfação do direito à memória e à verdade? } \\
\hline \multicolumn{2}{|c|}{ Brasil } & \multicolumn{2}{c|}{ Argentina } \\
\hline Ministros do STF & Posicionamento & Ministros da CSJN & Posicionamento \\
\hline CEZAR & NÃO MENCIONA & $\begin{array}{c}\text { ENRIQUE S. } \\
\text { PETRACCHI }\end{array}$ & SIM \\
\hline PELUSO & SIM & $\begin{array}{c}\text { CARLOS S. } \\
\text { FAYT }\end{array}$ & SIM \\
\hline GRAU & &
\end{tabular}




\begin{tabular}{|c|c|c|c|}
\hline $\begin{array}{c}\text { CELSO DE } \\
\text { MELLO }\end{array}$ & SIM & $\begin{array}{c}\text { ANTONIO } \\
\text { BOGGIANO }\end{array}$ & SIM \\
\hline $\begin{array}{c}\text { MARCO } \\
\text { AURÉLIO }\end{array}$ & NÃO MENCIONA & $\begin{array}{c}\text { JUAN CARLOS } \\
\text { MAQUEDA }\end{array}$ & SIM \\
\hline $\begin{array}{c}\text { ELLEN } \\
\text { GRACIE }\end{array}$ & NÃO MENCIONA & $\begin{array}{c}\text { EUGENIO RAÚL } \\
\text { ZAFFARONI }\end{array}$ & SIM \\
\hline $\begin{array}{c}\text { GILMAR } \\
\text { MENDES }\end{array}$ & NÃO MENCIONA & $\begin{array}{c}\text { ELENA I. HIGHTON } \\
\text { DE NOLASCO }\end{array}$ & SIM \\
\hline $\begin{array}{c}\text { AYRES } \\
\text { BRITTO }\end{array}$ & NÃO MENCIONA & $\begin{array}{c}\text { RICARDO LUIS } \\
\text { LORENZETTI }\end{array}$ & SIM \\
\hline $\begin{array}{c}\text { RICARDO } \\
\text { LEWANDOWSKI }\end{array}$ & SIM & $\begin{array}{c}\text { CARMEN } \\
\text { ARGIBAY }\end{array}$ & \\
\hline $\begin{array}{c}\text { CÁRMEN } \\
\text { LÚCIA }\end{array}$ & SIM & & \\
\hline
\end{tabular}

Fonte: Elaborado pelo autor da pesquisa com base nos Acórdãos da ADPF no 153

(STF, 2010) e do "Caso Simón" (CSJN, 2005).

Naquilo que se relaciona com o entendimento do STF sobre a realização do direito à memória e à verdade no caso brasileiro, encontram-se, conforme visto, poucos posicionamentos a respeito do tema por parte dos votantes. Entre os integrantes do STF que participaram das sessóes de julgamento da $\mathrm{ADPF}$, cinco não apresentaram um posicionamento sobre a questão (Ayres Britto, Ellen Gracie, Marco Aurélio, Cezar Peluso e Gilmar Mendes), enquanto os outros quatro Ministros votantes (Eros Grau, Cármen Lúcia, Ricardo Lewandowski e Celso de Mello) se posicionaram claramente a respeito do tema.

Embora nos seus votos não tenham se manifestado nem a favor nem contra as demandas por memória e verdade, os Ministros Ellen Gracie e Celso de Mello fizeram questão de referir que a vigência da Lei da Anistia, segundo ambos, não constituía impedimento ao esclarecimento dos fatos ocorridos na vigência da ditadura. Entre os votos favoráveis à realizaçáo dessas demandas no país, por sua vez, encontra-se uma divergência relacionada diretamente à própria decisão sobre a procedência dos pedidos contidos na ADPF: os que consideraram a Arguição improcedente (caso dos Ministros Eros Grau, Cármen Lúcia e Celso de Mello) se manifestaram em 
favor da busca pelo esclarecimento dos fatos ocorridos entre 1964 e 1985 e à difusão da memória do período, dissociando, contudo, a realização da memória e da verdade da obtenção da justiça; já o Ministro Lewandowski, que considerou o pedido de esclarecimento da Lei parcialmente procedente, considerou "memória, verdade e justiça" como direitos interdependentes, que devem ser realizados conjuntamente.

Ainda que todos os integrantes que participaram do julgamento do “Caso Simón” tenham apresentado um posicionamento favorável ao tema, é importante atentar, contudo, para uma diferença no que tange à concepção deste direito (ou conjunto de direitos). Com exceção do Ministro Fayt, os demais Ministros da Corte Suprema, ao mencionarem esse tema específico, demonstraram compreender o direito à memória e à verdade como um direito interdependente do direito à justiça. Ou seja, para a plena realização de um, é necessário garantir a satisfação dos demais.

Mesmo que em seu voto Fayt não chegue a considerar a realização da justiça como sendo algo desvinculado do eixo da memória e da verdade, fica claro que, para este Ministro, a busca pela justiça não requer que todos envolvidos em violaçôes sejam julgados, muito menos que, em algum momento, venham a ser previstos limites para a proposição de novas ações, como ocorreu na Argentina com as "leis de impunidade" (CSJN, 2005, p. 302-305).

\section{"Cada cabeça, uma sentença”: um balanço a partir das decisões sobre as leis de impunidade no Brasil e na Argentina}

Uma análise geral do resultado produzido no âmbito do julgamento da Arguiçáo pela Suprema Corte brasileira evidencia não só uma opção conservadora no que diz respeito ao tratamento do tema central da demanda, mas também, diante do silêncio ou do posicionamento fugidio de alguns Ministros a respeito de questóes politicamente relevantes (como é o caso da realização do direito à memória e à verdade), a falta de comprometimento dos seus integrantes para com o incremento e a formulação de uma agenda expressiva de políticas de memória para o país.

Atuando sob uma lógica que, alinhada aos objetivos políticos da transição, reforça a existência do consenso em detrimento da memória da repressáo, os Ministros do STF mostraram-se permeáveis a uma série de 
legados culturais e institucionais do autoritarismo no país, limitando o aprofundamento de uma cultura mais efetiva com vistas à realização dos direitos humanos, bem como reproduzindo práticas políticas que induzem o esquecimento, legitimam a impunidade e, se náo descaracterizam o caráter democrático do atual cenário político, relativizam a sua qualidade.

O resultado ao qual chegaram os Ministros da CSJN, por sua vez, pode ser entendido não só como um contraponto ao que foi decidido pelo STF mas também como uma demonstração de que a mais alta instância do Poder Judiciário argentino estava comprometida com uma agenda específica formada no cenário da transição. Pautados na defesa e concretização dos direitos humanos, os integrantes da Corte que consideraram as "leis de impunidade" inválidas, direta e indiretamente fortaleceram as demandas por memória, verdade e justiça, mostrando-se autônomos, pouco ou nada comprometidos com a possível manutenção ou reprodução de qualquer herança da ditadura.

Como visto nas seções anteriores, os Ministros do STF firmaram, pela maioria dos votos, um posicionamento visivelmente desfavorável ao uso do direito internacional dos direitos humanos em âmbito interno. Classificada como evidência do "provincianismo jurídico" da Corte brasileira por Deisy Ventura (2010), a decisão da ADPF, na prática, além de fornecer um embasamento jurídico que, mais uma vez, dificultaria a realização do direito à justiça no Brasil, contribuiu para a sedimentação de uma interpretação da transição política e dos pactos que dela fizeram parte como se estes devessem ser considerados como "contratos inalteráveis" no atual cenário político do país.

Mais do que isso, a decisão do STF a respeito da controvérsia em torno da Anistia demonstrou a força com que legados do autoritarismo gerados ou potencializados pela transiçáo negociada persistem no caso brasileiro. Não é por acaso, que na análise dos votos ficou bastante clara a interpretação, o entendimento dos Ministros, a respeito daquele que foi referido na parte inicial deste estudo como o principal legado da ditadura no país: a tese da anistia recíproca.

Em seus votos, os integrantes da Corte que consideraram a Arguição improcedente, concebem a lei e a interpretação favorável a não punição 
dos agentes da repressão como um "preço da transição" e como uma espécie de "condição" à reconciliação nacional. Sem demonstrar uma maior capacidade de problematização, parte dos Ministros do STF adere a uma interpretação limitada e questionável de acontecimentos da história recente do país, formulando votos condizentes com os interesses que o regime civil-militar impôs à distensão iniciada durante o Governo Geisel, e comprometidos, na atualidade, com uma leitura seletiva dos fatos que passa à margem do debate sobre a justiça.

Comparados, os posicionamentos dos Ministros no Brasil e na Argentina sobre o uso do direito internacional dos direitos humanos correspondem a uma visão sobre a questão que reflete o modo como a transição à democracia nesses países repercutiu na formulação de uma política nacional para o tema. Se na década de 1990 houve avanços significativos no que diz respeito ao estabelecimento de uma agenda nacional para os direitos humanos no Brasil, sendo realizada uma reaproximação do Estado brasileiro com o sistema internacional (KOERNER, 2003), a realização seletiva desses direitos no país continua sendo a regra, e não a exceção.

Apesar dos avanços, a impunidade das violaçóes bem como a sua continuidade no presente, são indícios de que o tema náo foi devidamente digerido pelo sistema político brasileiro com o retorno à democracia. Não é exagero, nesse sentido, afirmar que a falta de punição dos crimes da ditadura consolida a ideia de que a tortura é uma violência menos grave do que de fato é, colaborando para a naturalização da sua realização como mecanismo constante (e quase legítimo) de coerção por parte das forças de segurança".

$\mathrm{Na}$ Argentina, a defesa dos direitos humanos serviu de base para a construção da agenda política da nova democracia. Embora as demandas por memória, verdade e justiça tenham percorrido um caminho marcado por avanços e recuos nas décadas de 1980 e 1990, a internalizaçáo de normas de direito internacional dos direitos humanos ao sistema jurídico argentino, ocorrida em 1994 com a reforma constitucional, demonstra que o tema foi assumido como uma política de Estado efetiva pelo país,

II Nesse sentido, ver: Anistia Internacional, 2015; Cardia e Salla, 2014. 
possibilitando que, ao chegar à Corte Suprema, a posição majoritária sobre o tema tenha sido quase um contraponto à dos integrantes do STF.

Entre o discurso pró-direitos humanos e a prática, o Estado argentino parece ter realizado uma escolha decidida pela segunda opçáo, aplicando em âmbito interno normas elaboradas em instâncias internacionais, mesmo que estas não tenham sido devidamente internalizadas. Enquanto isso, o Estado brasileiro oscila entre as duas possibilidades, reproduzindo resquícios de uma cultura autoritária, ainda que isso implique a sua responsabilização perante a comunidade internacional e suas instâncias.

No que tange ao debate sobre a prescrição, a posição emitida por parte dos integrantes do STF, quando comparada ao resultado da CSJN, chama a atençáo para o modo com que outros legados culturais da ditadura também se fazem presentes no julgamento do caso. Nesse sentido, além de o Ministro Gilmar Mendes, conforme Acórdão da ADPF no 153 (STF, 2010, p. 238-239), apresentar sua argumentação com base na ideia de que "excessos" foram cometidos tanto por agentes da repressão como por militantes de esquerda, algo evidentemente alinhado à lógica dos militares no poder para justificar a violência política, outro colegas da Corte, caso do Ministro Ayres Britto (STF, 2010, p. 140), referiu que a tortura, a morte, o desaparecimento e a violação sexual, dentre outros crimes, seriam excessos e que quem os cometeu se tratava de algum tipo de "monstro".

Despojar de modo generalizado aqueles que praticam algum crime de seu equilíbrio mental ou considerá-los "monstros", é justamente aquilo que Hannah Arendt (1999), umas das principais filósofas políticas do século XX, notou como sendo algo bastante problemático quando do julgamento de Adolf Eichmann, criminoso nazista julgado, condenado e executado em Jerusalém na década 1960. Ignorar ou não reconhecer o fenômeno que Arendt denominou de "banalidade do mal", algo relacionado ao funcionamento do aparato repressivo instalado por uma ditadura, ajuda a legitimar uma cultura política segundo a qual o próprio ato de punir, em vez de ser dotado de objetividade, passa a ser entendido como algo subjetivamente justificado porque o autor do crime é um "monstro" ou porque o crime, em si, é algo terrível.

$\mathrm{Na}$ Corte Suprema de Justicia la Nación argentina, não foram objeto de apreciação aspectos subjetivos genericamente atrelados aos atos praticados 
durante a "guerra suja". Totalmente à margem de eventuais fragmentos culturais da ideologia de Segurança Nacional, os ministros argentinos se posicionaram, ainda que Fayt tenha divergido dos demais, respeitando critérios essencialmente técnicos, objetivos, naquilo que se referia à imprescritibilidade (ou não) dos crimes da ditadura.

Conscientes de que sua decisão incrementaria a busca por justiça na Argentina, por sinal, a maioria dos votantes mostrou que prerrogativas militares eventualmente mantidas nos primeiros anos após o retorno à democracia, como é o caso de normas que tenham possibilitado a não punição dos crimes do regime autoritário, não são necessariamente inquestionáveis, podendo ser revisadas de acordo com novos fatores conjunturais. No que se refere aos integrantes do STF, a maioria dos Ministros agiu de forma pouco protagônica, referendando a impunidade dos militares, e reforçando, em longo prazo, a manutenção das forças de segurança na qualidade de atores com poder de veto sobre temas politicamente relevantes.

Para não "reabrir feridas" (Acórdão da ADPF no 153, 2010, p. 155) ou, em outros termos, para evitar transtornos que seriam causados por parte das corporaçóes militares brasileiras na defesa de seus supostos "direitos adquiridos", os julgadores da Arguição também optaram pela frustração das vítimas da repressão (para não dizer da sociedade em geral) ao fazer uma defesa limitada do direito à memória e à verdade. Além de terem-no dissociado do direito à justiça, Ellen Gracie e Celso de Mello, por exemplo, afirmaram que a reconstituição da verdade e a memória do período estavam garantidas independentemente do julgamento da causa (Acórdão da ADPF no 153, 2010, p. 151-152 e 202). Como afirmar isso em um país onde, além do sigilo documental que vigorou durante décadas, a maior parte dos arquivos da repressão continua inacessível ou encontra-se sob a custódia indevida de militares da reserva e ex-agentes da repressão?

Se o acesso aos documentos produzidos pelos órgãos de segurança da ditadura que estão sob custódia do Estado brasileiro continua sendo dificultado a despeito das modificações na política nacional de sigilo vigentes desde 2012, é praticamente impossível garantir o direito à memória e à verdade sem poder levar à justiça os poucos agentes da repressão que ainda estão vivos. Afinal, se não há arquivos abertos para serem consultados, as 
únicas pessoas que poderiam esclarecer "como", "quando", "onde” e "por quem" foram mortos, desaparecidos e torturados centenas de militantes políticos, são, logicamente, aquelas pessoas que fizeram parte do aparato repressivo.

No caso argentino, memória, verdade e justiça, conforme referido na seção anterior, foram reconhecidos como direitos interdependentes por todos os membros da CSJN. Inclusive pelo Ministro Fayt, que votou pela manutenção das leis de "Punto Final" e "Obediencia Debida", divergindo pontualmente no que tange à possibilidade de que, segundo ele, em algum momento a busca pela justiça possa ser encerrada.

Se é fato que na Argentina existem problemas relacionados à custódia e manutenção da documentação sobre o período, é fato, igualmente, que isso não impediu, mesmo na vigência das "leis de impunidade", que parte da verdade sobre alguns acontecimentos fosse reconstituída. Afinal, nos "Julgamentos pela Verdade", ainda que não fosse possível haver punição para a maioria dos crimes cometidos, os testemunhos de vítimas e repressores serviram para a finalidade mencionada.

O problema, é que no caso brasileiro isso não está acontecendo pela via judicial. Ainda que as açóes judiciais propostas náo busquem a punição, mas exclusivamente efeitos declaratórios sobre alguma violação, a negativa da existência de documentos por parte das Forças Armadas persiste e a Lei de Anistia é constantemente invocada por advogados para justificar a extinção dos processos sem seu julgamento de mérito. Como consequência, protegidos pela tese da anistia recíproca tanto na esfera processual penal como na civil, os réus tumultuam o Judiciário apresentando recurso após recurso, imputando às vítimas da ditadura, na grande maioria dos casos, mais sofrimento ${ }^{12}$.

Sofrimento esse, que em vez de ser minimizado com a decisão do STF, foi, na realidade, por ela reforçado. Perdendo uma chance histórica de romper publicamente com elementos de uma legalidade autoritária

12 Ações judiciais como a que foi movida pela familia Teles em 2005, obtendo sentença reconhecendo o envolvimento de Carlos Alberto Brilhante Ustra (1932-2015) em atos praticados contra essa família de militantes políticos vinculados ao Partido Comunista do Brasil (PCdoB) na década de 1970, ainda são uma exceção. 
estabelecida pela ditadura, a decisão dos Ministros brasileiros, conforme Andrés Del Río (2014, p. 1192), “de forma armónica y selectiva, convalidó el pasado en el futuro y prohibió al futuro rever el pasado". Mais do que isso, e para além do impacto do Acórdáo junto às instituiçóes jurídicas, que acabaram permanecendo sem maiores incentivos institucionais para ampliar o debate sobre o tema em outros processos que tramitam nas instâncias inferiores, o resultado do julgamento certamente gera efeitos nocivos em diversos setores da sociedade.

Não é por acaso, nesse sentido, que na realização dos trabalhos da CNV tenha sido frequente a falta de colaboração de militares da reserva e da ativa com a entidade. Mesmo quando compareceram às audiências públicas para prestar esclarecimentos, poucos foram os que falaram algo que pudesse ajudar com as investigaçóes, sendo que, até aqueles que fizeram revelaçóes mais impactantes, caso do militar Paulo Malhães ${ }^{13}$, o fizeram sentindo-se plenamente seguros de que gozavam da impunidade referendada pelo STF.

São condutas como essas que ajudam a reforçar junto à sociedade a crença em ideias como a de que a impunidade é natural, que a violência é justificada em alguns casos e, até mesmo, de que um regime de exceçáo é aceitável dependendo da conjuntura. Não é de se surpreender, portanto, que em uma consulta à plataforma on-line do Latinobarómetro e do World Values Survey encontrem-se dados que demonstram como alguns traços culturais autoritários se fazem presentes (em maior ou menor grau) nos países que estão sendo analisados.

13 Paulo Malhães (1938-2014), militar do Exército na época da ditadura, prestou depoimentos polêmicos para Comissão da Verdade, primeiramente confirmando sua participação na tortura e ocultação de cadáveres; depois, negando parte dos fatos. Pouco tempo após conceder novo depoimento, Malhães foi encontrado morto em sua residência em Nova Iguaçu (RJ). 
Tabela I - Preferência por regime: apoio à democracia

\begin{tabular}{c|c|c|c|c|c|c|c|c|c|c}
\hline ANO BASE & 1995 & $\mathbf{2 0 0 0}$ & $\mathbf{2 0 0 5}$ & $\mathbf{2 0 1 0}$ & $\mathbf{2 0 1 5}$ & & & & & \\
\hline $\begin{array}{c}\text { QUESTÃO / } \\
\text { PAÍS }\end{array}$ & ARG & BRA & ARG & BRA & ARG & BRA & ARG & BRA & ARG & BRA \\
\hline $\begin{array}{c}\text { Democracia } \\
\text { é preferível a } \\
\text { qualquer forma } \\
\text { de governo }\end{array}$ & $76 \%$ & $41 \%$ & $70 \%$ & $38 \%$ & $66 \%$ & $37 \%$ & $66 \%$ & $54 \%$ & $70 \%$ & $54 \%$ \\
\hline $\begin{array}{c}\text { Em algumas } \\
\text { circunstâncias, } \\
\text { um governo } \\
\text { autoritário pode } \\
\text { ser preferível }\end{array}$ & $11 \%$ & $21 \%$ & $16 \%$ & $25 \%$ & $17 \%$ & $15 \%$ & $19 \%$ & $19 \%$ & $15 \%$ & $16 \%$ \\
\hline $\begin{array}{c}\text { Não importa } \\
\text { se o regime é } \\
\text { democrático }\end{array}$ & $6 \%$ & $23 \%$ & $12 \%$ & $28 \%$ & $11 \%$ & $28 \%$ & $13 \%$ & $15 \%$ & $13 \%$ & $16 \%$ \\
\hline Não respondeu & $1 \%$ & $1 \%$ & $1 \%$ & $2 \%$ & $1 \%$ & $1 \%$ & $0 \%$ & $0 \%$ & $0 \%$ & $1 \%$ \\
\hline $\begin{array}{c}\text { Não sabe } \\
\text { Entrevistados }\end{array}$ & 1.200 & 1.200 & 1.200 & 1.000 & 1.200 & 1.204 & 1.200 & 1.204 & 1.200 & 1.250 \\
\hline
\end{tabular}

Fonte: Latinobarómetro (20/8).

A Tabela 1 demonstra, com dados que abrangem uma série temporal de duas décadas, que os argentinos, de forma geral, possuem uma preferência maior pela democracia do que os brasileiros. Se, por um lado, e com o passar dos anos, os dois países apresentam percentuais muito próximos de preferência por governos autoritários, por outro, os entrevistados na Argentina afirmaram preferir a democracia em comparação com qualquer outra forma de governo em percentual sempre superior aos 66\%, enquanto no Brasil os maiores percentuais chegam a 54\% em 2010 e 2015 . Ou seja, e no contexto brasileiro, até terem passado pelo menos 20 anos após a saída dos militares das estruturas de poder no país, a média de apoio à democracia se manteve muito abaixo da argentina. No caso argentino, fica evidente o apoio à democracia. Embora a média oscile em alguns momentos, o índice se mantém elevado desde a década de 1990, sendo igual a $70 \%$ no ano de 2015 , quando se completaram 30 anos do julgamento das 
Juntas Militares que governaram o país entre 1976 e 1983. Como se pode notar, portanto, o que diferencia a percepção dos cidadãos dos dois países nem é tanto a preferência por um regime autoritário, mas sim a convicção a respeito do regime democrático como sendo a melhor forma de governo.

Tabela 2 - Papel das Forças Armadas em democracias

\begin{tabular}{c|c|c}
\hline \multirow{2}{*}{ País } & \multicolumn{2}{|c}{$\begin{array}{c}\text { Afirmação: As Forças Armadas assumirem o governo } \\
\text { caso ele se mostre incompetente é uma característica } \\
\text { fundamental da democracia }\end{array}$} \\
\hline \multirow{2}{*}{ Argentina } & Discorda totalmente & Concorda totalmente \\
\hline Brasil & $43,3 \%$ & $4,0 \%$ \\
\hline
\end{tabular}

Fonte: Elaborada pelo autor da pesquisa mediante acesso à base de dados do World Values Survey, $6^{a}$ Onda (pesquisa realizada em 2013, na Argentina, e em 20/4, no Brasil). Na Argentina (N) = 1030, para o Brasil $(N)=1486$.

Tabela 3 - Percepção sobre o tipo de sistema político: governo militar

Vou descrever alguns tipos de sistema político e gostaria de saber o que o(a) Sr.(a) pensa sobre cada um deles como modo de governar o país. Para cada um, diga se é ótimo, bom, ruim ou péssimo.

Tipo de sistema político mencionado pelo entrevistador: um governo militar

\begin{tabular}{c|c|c}
\hline Percepção / País & Argentina & Brasil \\
\hline Ótimo & $1,9 \%$ & $7,3 \%$ \\
\hline Bom & $8,0 \%$ & $24,8 \%$ \\
\hline Ruim & $22,7 \%$ & $35,2 \%$ \\
\hline Péssimo & $58,2 \%$ & $24,8 \%$ \\
\hline
\end{tabular}

Fonte: Elaborada pelo autor da pesquisa mediante acesso à base de dados do World Values Survey, $6^{a}$ Onda (pesquisa realizada em 2013, na Argentina, e em 2014, no Brasil). Na Argentina $(N)=1030$, para o Brasil $(N)=1486$. 
$\mathrm{Na}$ Tabela 2, por exemplo, verifica-se que, enquanto apenas 4\% dos argentinos entrevistados considera legítima a intervenção das Forças Armadas caso o governo demonstre ser incompetente, para 18,6\% dos brasileiros (quase 1/5 dos entrevistados) uma situação como esta seria considerada como uma característica fundamental em uma democracia. De modo semelhante, ainda nessa tabela constata-se que um número maior de argentinos, $43,3 \%$, discorda da afirmação do entrevistador, enquanto $27,9 \%$ dos brasileiros, menos de $1 / 3$ da amostra, se posicionam deste modo.

Quando o dado que se analisa no World Values Survey é a percepção dos entrevistados sobre o tipo de sistema político, constata-se novamente a persistência de uma visão mais condescendente, entre os brasileiros, para com um regime autoritário. Nesse sentido, observa-se na Tabela 3 que para $58,2 \%$ (quase 2/3) dos argentinos é considerado "péssimo" ter um governo militar no comando do país, ao passo que apenas $1,9 \%$ da população entrevistada considerava "ótimo" este sistema político. Entre os brasileiros, $24,8 \%$ (quase $1 / 4$ dos participantes da pesquisa) consideram "péssimo" ter um governo militar, e 7,3\% "ótimo" viver sob o comando dos militares.

Se à primeira vista os dados da Tabela 3 não parecem significativos no sentido que foi afirmado alguns parágrafos acima, é interessante notar que, ao somar as frequências das categorias "bom" e "ótimo", se verifica que apenas $9,9 \%$ dos argentinos possuem uma visão positiva da ocupação do poder pelas Forças Armadas, enquanto 32,1\% dos brasileiros, quase 1/3 da amostra, crê que a hipótese apresentada pelo pesquisador é, em tese, pelo menos boa.

Uma pergunta que poderia persistir diante desses dados seria: como esperar mudanças comportamentais em curto, médio e longo prazo, dotando uma democracia de maior qualidade, se, na prática, boa parte dos termos da "agenda da transição" se mantêm, possibilitando a renovação constante de legados da ditadura no país?

Os votos dos Ministros em cada país analisado, por sinal, também podem ser relacionados à opinião emitida pelos entrevistados ao Latinobarómetro (2018) e ao World Values Survey (2018). Afinal, por qual razão os integrantes do STF iriam se posicionar favoráveis à punição dos crimes da ditadura se parcelas significativas da população desconhecem esses fatos 
ou, em uma situação limite, talvez sejam indiferentes ao tipo de regime político vigente?

Na Argentina, o Poder Judiciário foi reestruturado na nova democracia, sendo impedido, aos Ministros da CSJN nomeados pelo regime de exceção, a sua permanência no cargo. No Brasil, não houve uma reforma das instituiçóes judiciárias após a saída das Forças Armadas do poder, e Ministros do STF nomeados pela ditadura continuaram exercendo seus mandatos até o início dos anos $2000^{14}$. Não causa estranheza, portanto, que na falta de constrangimentos institucionais e culturais para se mostrarem autônomos diante de resquícios autoritários, os integrantes da Corte brasileira tenham sido em sua maioria contrários à ADPF no 153.

\section{Considerações finais}

A comparação dos votos proferidos pelos participantes das votaçóes aqui analisadas denota, à primeira vista, a maneira como uma eventual dificuldade para resolver a tensão entre "objetividade" e "subjetividade" foi encarada por parte dos votantes. Enquanto os votos dos Ministros brasileiros foram marcados pelo uso de argumentos mais subjetivos para a tomada de decisão, sendo apresentada pela maioria dos votantes uma interpretação excessivamente parcial do contexto da transição e de fatos da ditadura brasileira, os votos apresentados pela CSJN na análise do "Caso Simón" são mais bem fundamentados do ponto de vista técnico, sendo o debate focado essencialmente em questóes objetivas, relacionadas principalmente à técnica-jurídica.

Outro aspecto que chama a atenção na análise das decisóes se relaciona com o uso da normativa internacional sobre direitos humanos. Enquanto a decisão da CSJN emite, pela maioria esmagadora dos votos, um posicionamento comprometido com o cenário político argentino, que à época estava alinhado às exigências políticas e jurídicas vigentes tanto em âmbito interno, como no plano internacional, no Acórdão da ADPF evidencia-se

14 Estudos focados no impacto das ditaduras e dos processos transicionais no Poder Judiciário elou nas Supremas Cortes argentina e brasileira podem ser encontrados em: Aguilar, 2013; Del Rio, 2018; Pereira, 2010; Recondo (20/8). 
a desconsideração, por parte da maioria dos Ministros, para com a própria evolução da normativa internacional referente aos direitos humanos pós-Segunda Guerra Mundial.

Ademais, não é, igualmente, por outro motivo, que na decisão do STF perceba-se quase que uma reverência seletiva ao passado, justamente naqueles aspectos que se relacionam com a manutenção das garantias angariadas pelas elites civis e militares durante a distensão. Em seus votos, a maior parte dos votantes não se compromete com o direito à memória e à verdade, uma vez que não entra no debate sobre o acesso aos arquivos da repressão; não se compromete com princípios de justiça estabelecidos na ordem internacional, afastando a aplicabilidade do direito internacional dos direitos humanos para o caso; e, reproduzindo uma análise de conjuntura que tende a diluir entre agentes da repressão e opositores a "culpa” pelos excessos cometidos, reforça resquícios culturais da DSN junto à sociedade, que, diante do resultado do julgamento, banaliza a violência e a impunidade.

Sem a intenção de apresentar o caso argentino como um modelo a ser seguido por outros países que passaram por experiências semelhantes, o objetivo da comparação era, justamente, evidenciar fatores que ajudassem a explicar as diferenças na formulação dos julgamentos. Os dados selecionados para este estudo, nesse sentido, ajudaram a identificar elementos suficientes para que seja possível afirmar, com alguma margem de segurança, que o tipo de transição ocorrida pode impactar em longo prazo no novo regime, de modo que, em contextos políticos onde ocorreram transiçóes mais negociadas, há maiores dificuldades para se romper com legados da ditadura.

Entender o modo como se deu a transição à democracia nos países analisados, é claro, não possibilita a formulação de uma explicação total para as diferenças existentes no modo como questóes relacionadas aos crimes da ditadura vêm sendo enfrentadas em cada contexto. Isso não constitui impedimento; entretanto, para que possa ser observado que a forma como essas ditaduras chegaram ao fim no Brasil e na Argentina, parece ter gerado efeitos no âmbito dessas políticas, visto que esses regimes autoritários deixaram uma série de legados que, na consolidação das novas democracias, foram sendo mantidos ou tiveram seu impacto reduzido gradativamente. 
Para o caso brasileiro, vê-se que persiste uma maior dificuldade de avançar no debate sobre o tema possivelmente influenciada pela dinâmica da transição "lenta, gradual e segura”. Sendo perceptível que a construção de uma agenda sobre o tema no país vem sendo realizada de maneira que os avanços que se quer produzir sempre estão limitados ou comprometidos com os termos estabelecidos durante as negociaçóes que culminaram com a entrega do poder aos civis em março de 1985.

No caso argentino, onde a saída dos militares das estruturas de poder foi abrupta, havendo margem reduzida para o estabelecimento de garantias a serem mantidas na vigência do novo regime, o debate político imediatamente posterior ao fim da ditadura foi permeado pela defesa dos direitos humanos, sendo constituídas as bases para a construção de uma agenda específica sobre o tema, e que, mesmo que tenha sido marcada por avanços e recuos, mostra-se autônoma diante dos legados autoritários que eventualmente foram instrumentalizados na nova democracia.

Outros aspectos do cenário sociopolítico também são importantes. $\mathrm{O}$ debate sobre políticas de memória mudou bastante nos dois países nos últimos 30 anos, variando de acordo com fatores conjunturais de ordem externa e interna. A contribuição pessoal do presidente Néstor Kirchner e da maioria dos Ministros da CSJN para o aprofundamento dessas demandas, demonstram o papel protagônico (e até mesmo decisivo) que atores políticos podem desempenhar em contextos específicos. Alguns fatos polêmicos durante o Governo de Maurício Macri, iniciado em 2015, neste sentido, dão evidência de como uma mudança governamental pode repercutir no apoio à causa ${ }^{15}$. Não fosse a massiva manifestação popular que ocorre a cada tentativa de interromper o avanço dos julgamentos pelos crimes da ditadura, entre outros fatores, certamente as demandas por memória, verdade e justiça poderiam ser limitadas no país vizinho.

15 Entre outros acontecimentos, faz-se referência: a) ao questionamento, em janeiro de 2016, do número de desaparecidos políticos por parte de Darío Lopérfido, à época Ministro da Cultura do Governo Macri; b) à manifestação, por parte do próprio presidente Macri, em agosto de 2016, dizendo não saber exatamente quantos desaparecidos políticos existiam no país, algo que reforçava versões que questionam o alcance da repressão; c) às tentativas de que agentes da repressão condenados à prisão fossem beneficiados com redução de pena entre outras medidas. Todos os fatos mencionados foram bastante noticiados, tendo gerado uma série de protestos por parte de organizações de direitos humanos e grupos de familiares de vítimas da ditadura no país. 
Enquanto os julgamentos na Argentina vêm percorrendo um caminho de lutas que, envolvendo amplos setores da sociedade, é marcado por grandes avanços em direção à reconstituição da memória, da verdade e, após 2005, a uma nova etapa de realização da justiça, as possibilidades de reconstituição do passado recente no Brasil continuam seguindo uma trajetória marcada por uma disputa de interesses bastante desigual. Nela, ainda que a difusão de novos fatos sobre as violaçóes ocorridas tenha sido intensificada na última década, parcelas significativas da sociedade seguem alheias ao debate. Enquanto isso, grupos de vítimas da repressão, militantes e organizaçóes de direitos humanos tentam ampliar seu poder de agenda, disputando espaço com pessoas, setores e instituiçôes públicas e privadas comprometidas com o "esquecimento", bem como lutando contra o tempo, que avança sobre os sobreviventes.

Isso significa que um país que possua maiores dificuldades para superar resquícios autoritários será eterna e necessariamente "refém do seu passado"? Como demonstra o caso argentino, situaçóes específicas ocorridas na vigência da nova democracia podem relativizar a força da causa dos direitos humanos em alguns períodos. Embora difícil e até mesmo improvável, mudanças no enfrentamento do tema podem ocorrer mesmo em contextos como o brasileiro, no qual a indução ao esquecimento parece ter se constituído como o principal legado da ditadura para a nova democracia.

\section{Referências}

AGUILAR, P. Jueces, represión y justicia transicional en España, Chile y Argentina. Revista Internacional de Sociología (RIS), Madrid, v. 71, n. 2, p. 281-308, 2013.

ANISTIA INTERNACIONAL. Informe 2014/15: o estado dos direitos humanos no mundo. Rio de Janeiro: Anistia Internacional Brasil, 2015.

ARENDT, H. Eichmann em Jerusalém: um relato sobre a banalidade do mal. São Paulo: Companhia das Letras, 1999.

ARTURI, C. S. O debate teórico sobre mudança de regime político: o caso brasileiro. Revista de Sociologia e Política, Curitiba, n. 17, p. 11-31, 2001.

BADIE, B.; HERMET, G. Política comparada. México: Fondo de Cultura Económica, 1993.

BRITO, A. B. de; AGUILAR, P.; GONZÁLEZ, C. (Org.). Las políticas hacia el pasado: juicios, depuraciones, perdón y olvido en las nuevas democracias. Madrid: Istmo, 2002. 
CALADO, R. Políticas de memória na Argentina (1983-2010). Transiçáo política, justiça e democracia. História - Revista da FLUP, Porto, v. 6, n. 4, p. 51-64, 2014.

CARDIA, N.; SALLA, F. Um panorama da tortura no Brasil. In: CARDIA, N.; ASTOLFI, R. (Org.). Tortura na Era dos Direitos Humanos. São Paulo: Edusp, 2014. p. 315-358.

Centro de Estudios Legales y Sociales (CELS). La fuerza de la verdad, el tiempo de la justicia. In: Centro de Estudios Legales y Sociales (CELS). Derechos humanos en Argentina: informe 2010. Buenos Aires: Siglo Veintiuno Editores, 2010. p. 61-108.

Corte Suprema de Justicia de la Nación argentina (CSJN). Caso Simón. 2005. Disponível em:https://sjconsulta.csjn.gov.ar/sjconsulta/documentos/verDocumentoSumario. html?idDocumentoSumario=11294. Acesso em: 12 abr. 2019.

DEL RÍO, A. Dictadura, democracia y justicia transicional en Brasil: trayectoria y legados del Supremo Tribunal Federal. Dados - Revista de Ciências Sociais, Rio de Janeiro, v. 57, n. 4, p. 1169-1201, 2014

DEL RÍO, A. Supreme Court, institutional change and authoritan regimes: Argentina and Brazil (1964-1985). Razón Crítica, v. 2, n. 4, p. 75-103, jun. 2018.

HUNTINGTON, S. P. A terceira onda: a democratização no final do Século XX. São Paulo: Ática, 1994.

KOERNER, A. O papel dos direitos humanos na política democrática: uma análise preliminar. Revista Brasileira de Ciências Sociais, v. 18, n. 53, p. 143-157, out. 2003.

LANDMAN, T. Política comparada: una introducción a su objecto y métodos de investigación. Madrid: Alianza Editorial, 2011.

LATINOBARÓMETRO. 2018. Disponível em: http://www.latinobarometro.org/lat.jsp. Acesso em: 12 abr. 2019.

MORLINO, L. Legados autoritários, política do passado e qualidade da democracia na Europa do Sul. In: PINTO, A. C.; MARTINHO, F. C. P. (Org.). O passado que náo passa: a sombra das ditaduras na Europa do Sul e na América Latina. Rio de Janeiro: Civilização Brasileira, 2013. p. 261-294.

MUNCK, G.; LEFF, C. Modes of Transition and Democratization: South America and Eastern Europe in comparative perspective. Comparative Politics, v. 29, n. 3, p. 343-362, 1997.

NOHLEN, D. Ciencia política comparada: el enfoque histórico-empírico. Granada: Editorial Universidad de Granada, 2013.

NORRIS, R. E. Leyes de impunidad y los derechos humanos en las Américas: una respuesta legal. Revista del Instituto Interamericano de Derechos Humanos, San José, v. 8, n. 15, p. 47-121, 1992. NOVARO, M.; PALERMO, V. La ditadura militar (1976-1983): del Golpe de Estado a la restauración democrática. Buenos Aires: Paidós, 2003. 
O'DONNELL, G.; SCHMITTER, P. Transiçóes do regime autoritário: primeiras conclusôes. São Paulo: Vértice/Revista dos Tribunais, 1988a.

O'DONNELL, G.; SCHMITTER, P.; WHITEHEAD, L. (Org.). Transiçóes do regime autoritário: Sul da Europa. São Paulo: Vértice/Revista dos Tribunais, 1988b.

O’DONNELL, G.; SCHMITTER, P. WHITEHEAD, L. (Org.). Transiçóes do regime autoritário: América Latina. São Paulo: Vértice/Revista dos Tribunais, 1988c.

PADRÓS, E. S. Repressão e violência: segurança nacional e terror de Estado nas ditaduras latinoamericanas. In: FICO, C. et al. (Org.). Ditadura e democracia na América Latina: balanço histórico e perspectivas. Rio de Janeiro: Editora FGV, 2008. p. 143-178.

PEREIRA, A. W. Ditadura e repressáo: o autoritarismo e o estado de direito no Brasil, no Chile e na Argentina. Rio de Janeiro: Paz e Terra, 2010.

PINTO, A. C. O passado autoritário e as democracias da Europa do Sul: uma introduçáo. In: PINTO, A. C.; MARTINHO, F. C. P. (Org.). O passado que não passa: a sombra das ditaduras na Europa do Sul e na América Latina. Rio de Janeiro: Civilização Brasileira, 2013. p. 17-45.

RAUSCHENBERG, N. D. B. Memória e justificação no processo de justiça transicional argentino: da reconstrução democrática às "megacausas" (1983-2013). História Unisinos, São Leopoldo, v. 18, n. 3, p. 572-588, set./dez. 2014.

RECONDO, F. Tanques e togas: o STF e a ditadura militar. Sáo Paulo: Companhia das Letras, 2018.

SUPREMO TRIBUNAL FEDERAL (STF). Arguição por Descumprimento de Preceito Fundamental (ADPF) no 153, julgada em abril de 2010. Disponível em: http://redir.stf.jus.br/ paginadorpub/paginador.jsp?docTP=AC\&docID=612960. Acesso em: 12 abr. 2019.

VENTURA, D. A interpretação judicial da Lei de Anistia brasileira e o direito internacional. Revista Anistia Política e Justiça de Transição, Brasília, v. 2, n. 4, p. 196-226, jul./dez. 2010.

WORLD VALUES SURVEY. 2018. Disponível em: http://www.worldvaluessurvey.org/wvs.jsp. Acesso em: 12 abr. 2019.

\section{The past in the dock: an analysis of the decisions of the Argentine and Brazilian Supreme Courts on the validity of the "laws of impunity"}

\section{Abstract}

This work makes a comparative analysis of the judgment of lawsuits that questioned the validity of laws that guarantee the impunity of the sectors involved with the political repression during the National Security dictatorships. For the comparison, two cases were selected for analysis: the "Simón Case", judged in June 2005 by the Argentine Supreme Court of Justice, and the ADPF 
153, judged in April 2010 by the Brazilian Federal Supreme Court. The decisions are compared and, after, we try to identificate what explains them, verifying their connection with the politics of memory that have been implemented in each context.

Keywords: National Security Dictatorships. Judiciary Power. Politics of memory.

Recebido em: 20/06/2018

Aprovado em: 03/09/2018 